\title{
Occupational asthma due to unheated colophony
}

\author{
PS BURGE, A WIELAND, AS ROBERTSON, AND D WEIR
}

From the Department of Thoracic Medicine, East Birmingham Hospital, Bordesley Green East, Birmingham B9 5ST, UK

Occupational asthma due to colophony is well recognised in the electronics industry where colophony forms part of the soldering flux. ${ }^{1-5}$ The colophony heated at soldering temperature $\left(350-450^{\circ} \mathrm{C}\right)$ undergoes some decomposition, raising the possibility that the occupational asthma may be due to colophony breakdown products rather than to the colophony resin acids themselves. In the United Kingdom this has resulted in occupational asthma due to colophony being recognised as a prescribed disease only after exposure to electronic soldering flux. There have been isolated case reports of occupational asthma when the colophony was heated to lower temperatures; in particular a machine tool setter developed occupational asthma reproduced by heating colophony at $180^{\circ} \mathrm{C}^{6}$ and a chemical worker developed occupational asthma when making colophony derivatives heated to $90^{\circ} \mathrm{C}^{7}$ We report the first case in which asthma has been induced by exposure to colophony at room temperature.

\section{Case report}

A 53 year old man developed tightness of the chest and wheeze three weeks after starting work making a bitumen mixture containing colophony. Regular symptoms of chest tightness developed in the afternoon at work and progressed into the evening at home. He sometimes woke up short of breath during the night and was breathless on waking the following morning. The symptoms occurred similarly on all days when he worked with colophony and was somewhat better on Saturdays away from work and considerably better on Sundays away from work and on holidays. He also developed rhinitis with less improvement at the weekends. His asthma was also provoked by respiratory infections, exercise, and fog and his rhinitis by grass pollen.

At work he extracted solid colophony from a drum by hitting it with a large hammer and then shovelling the ground up colophony into a weighing cylinder. In a separate room the colophony was added to bitumen, linseed oil, and Wingstay powder, heated at $120^{\circ} \mathrm{C}$ to make varnish.

Accepted 3 December 1985
SERIAL MEASUREMENTS OF PEAK FLOW AT HOME AND WORK

Peak expiratory flow rate was measured every two hours from waking to sleeping over a ten week period as previously described. ${ }^{8}$ Part of this record is shown in fig 1 . It shows some fall in minimum peak flow while working making varnish (with minor exposure to colophony) and a considerable further fall in peak flow when working with colophony on the last two days of each work week, with recovery taking at least three days after exposure.

\section{BRONCHIAL PROVOCATION TESTING}

Bronchial provocation testing was carried out as an inpatient, on the first day by tipping between two trays the non-colophony particulate additives to the bitu-

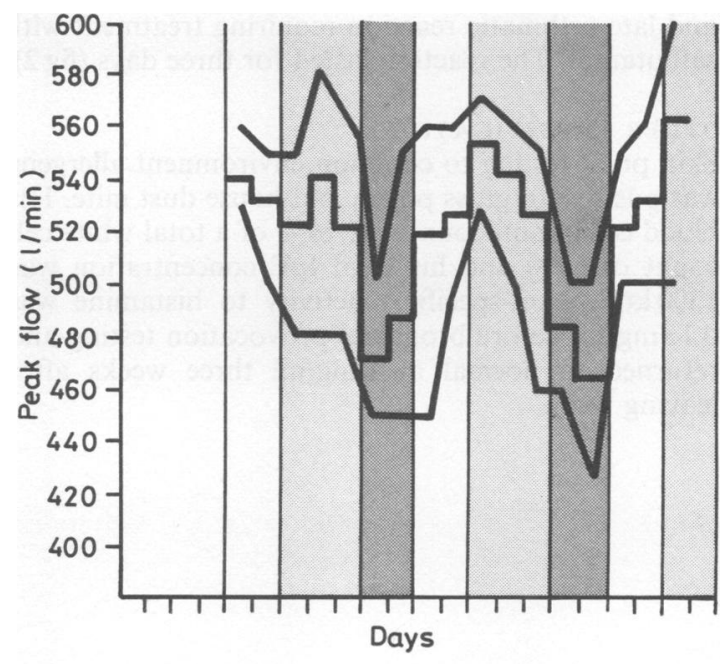

Varnish making

Crushing resin

Fig 1 Daily maximum (top line), mean (middle line), and minimum (bottom line) peak expiratory flow. Measurements were taken every two hours from waking to sleeping. Days at work have a shaded background, days away from work a plain background. Beclomethasone (Becotide) $200 \mu \mathrm{g}$ twice daily, salbutamol tablets $4 \mathrm{mg}$ thrice daily, and salbutamol by inhalation $200 \mu \mathrm{g}$ every four hours were taken throughout the record. 


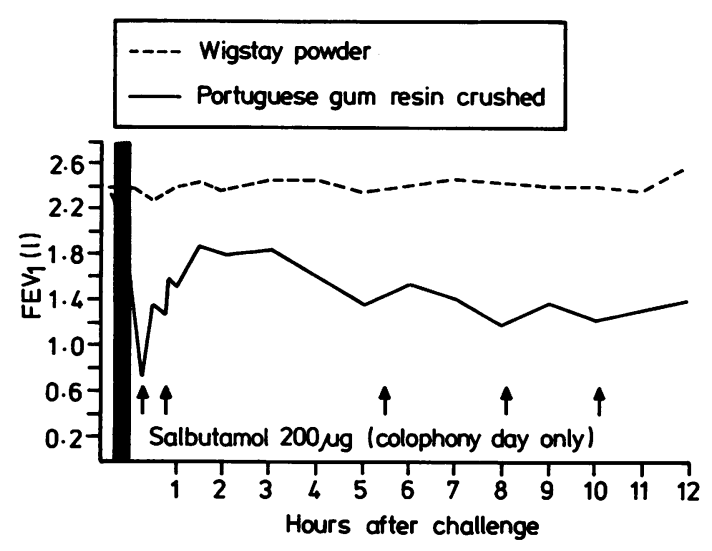

Fig $2 F_{1}$ after exposure to crushed colophony at room temperature (lower trace) and other particulate constituent of bitumen mix (upper trace).

men mixture (Wingstay powder). There was no significant reaction after 10 minutes' exposure. On the second day he crushed solid colophony with a hammer and tipped the particles between two trays for 15 minutes. This was followed by a significant immediate and late asthmatic reaction requiring treatment with salbutamol. The reaction lasted for three days (fig 2 ).

\section{OTHER INVESTIGATIONS}

Skin prick testing to common environment allergens was positive to grass pollen and house dust mite. His blood eosinophil count was $16 \%$ of a total white cell count of 6000 and his total IgE concentration was $1300 \mathrm{ku} / \mathrm{l}$. Non-specific reactivity to histamine was $0.13 \mathrm{mg} / \mathrm{ml}$ before bronchial provocation testing and returned to normal at $8 \mathrm{mg} / \mathrm{ml}$ three weeks after leaving work.

\section{Conclusion}

Our patient had classic symptoms of occupational asthma that developed when crushing colophony at room temperature. He may also have been exposed to some fumes from heated colophony when added to the bitumen mixture. His symptoms, however, were reproduced by exposure to colophony at room temperature. This provides further evidence that the cause of occupational asthma from colophony is due to the intact resin acids rather than decomposition products from them. Colophony fumes are most often inhaled in a heated form, resulting in the more common occurence of occupational asthma from heated colophony. We have shown, however, that inhaling particulate colophony can also result in occupational asthma. Colophony capable of being inhaled in any form should be regarded as a cause of occupational asthma and steps should be taken to reduce all occupational exposure to inhalable colophony.

\section{References}

${ }^{1}$ Fawcett IW, Newman Taylor AJ, Pepys J. Asthma due to inhaled chemical agents-fumes from "Multicore" soldering flux and colophony resin. Clin Allergy 1976;6:577-85.

${ }^{2}$ Oziganova VN, Ivanova IS, Dueva LA. Bronchial asthma in radio equipment assemblers. Sov Med 1977;4:139-41.

${ }^{3}$ Burge PS, Harries MG, O'Brien IM, Pepys J. Respiratory disease in workers exposed to solder flux fumes containing colophony (pine resin). Clin Allergy 1978;8:1-14.

4 Burge PS, Harries MG, O'Brien IM, Pepys J. Bronchial provocation studies in workers exposed to the fumes of electronic soldering fluxes. Clin Allergy 1980;10:137-49.

5 Burge PS, Perks WH, O'Brien IM, et al. Occupational asthma in an electronics factory: a case control study to evaluate aetiological factors. Thorax 1979;34:300-7.

${ }^{6} \mathrm{Hendy}$ MS, Beattie BE, Burge PS. Occupational asthma due to an emulsified oil mist. Br J Ind Med 1985;42:51-4.

${ }^{7}$ Innocenti A, Loi F. Occupational asthma due to sensitisation to the fumes of colophony. Med Lav 1978;69:720-2.

${ }^{8}$ Burge PS. Single and serial measurements of lung function in the diagnosis of occupational asthma. Eur J Respir Dis 1982;63 (suppl 123):47-59. 